\title{
ECOLOGICAL AND ECONOMIC SUSTAINABILITY OF POLISH AND LITHUANIAN AGRICULTURAL HOLDINGS SPECIALIZING IN ANIMAL PRODUCTION ${ }^{*}$
}

\author{
Zofia KOLOSZKO-CHOMENTOWSKA, Bialystok University of Technology, ul. Wiejska 45A, 15-351 Białystok, Poland, \\ z.koloszko@pb.edu.pl \\ Jan ŽUKOVSKIS, Faculty of Economics and Management, Aleksandras Stulginskis University, Studentu g. 11, LT-53361 \\ Akademija, Kaunas raj., Lithuania, jan.zukovskis@asu.lt \\ Audrius GARGASAS, Faculty of Economics and Management, Aleksandras Stulginskis University, Studentu g 11, LT-53361 \\ Akademija, Kaunas raj., Lithuania, audrius.gargasas@asu.lt
}

In the present article, an attempt was made to assess the environmental and economic sustainability of Polish and Lithuanian agricultural holdings specializing in animal production. The analysis covers the farms that participated in the FADN in 2006-2012. Assessment accounted for agroecological indicators (share of cereals in crops, stock density) and economic indicators (profitableness of land and labour). Analysis was conducted according to a classification into agricultural holding types: dairy cattle and granivores.

In both countries, average stocking density in dairy holdings did not pose a threat to the natural environment. In the case of granivores holdings, such threats were present because standards specified in the code of good agricultural practice were violated significantly. From the perspective of economic equilibrium, holdings from this group achieved a better result than dairy cattle holdings. In Poland during the years 2006-2012, the average income of a family-owned agricultural holding per full-time worker in the family was $56 \%$ greater than in dairy cattle holdings. In the case of Lithuanian holdings, the difference was still greater and amounted to $73 \%$ to the benefit of granivores holdings.

Keywords: sustainability, agricultural holdings, animal production

\section{INTRODUCTION}

Agricultural production exhibits particularly strong ties to environmental order, because it utilizes natural resources to a greater extent than other sectors of the economy, and their status and existing equilibrium are of great significance to the volume and quality of food (Woś, 1998). This is linked to the intensification of production, which is unavoidable in the modern world. Modeling of production processes and of the functioning of agricultural holdings in accordance with the principles of permanent sustainable development, as well as a new perspective on the intensification of production and its limits, are among the most important problems in agricultural economics. Sustainability of agricultural holdings is treated as a priority in EU Common Agricultural Policy, which is reflected in the financial policy for 2014-2020. Sustainability conditions are different for agricultural holdings than for the entire agricultural sector, and thus there it is necessary to conduct assessment at different levels. The results indicate that agri-environmental schemes and specific rural development measures effect the changes in the indicators. In particular results indicate that trends observed at the national scale do not necessarily apply at the regional scale (Desjeux et al., 2015). The specific habitat, economic and organizational conditions of agriculture also have an impact on sustainability assessment, and equilibrium states change under the influence of many factors. This variability of conditions justifies the need for systematic research in this scope.

An agricultural holding's impact on the natural environment is dependent on its specialization. This is confirmed by analyses conducted in holdings with different directions of production (Castoldi et al., 2010; Escribano et al., 2014; Belanger et al., 2012). The technological, biological, and organizational progress that is now taking place provides access to increasingly modern and effective technologies. This leads to improvement of the technical and economic efficiency of agricultural production, but it also causes a series of unfavorable phenomena such as deterioration of animal welfare or threats to the natural environment. Therefore, there is a need to integrate measures initiating the search for solutions intended to conserve the features of the natural environment while allowing for the achievement of economic objectives.

Specialized holdings successfully achieve their economic objective, however environmental limitations are linked to their development. This particularly pertains to animal production. In this case, limitations concern potential threats arising from agricultural management of animal excrements. Canada intiated an agri-environmental indicators 
programme, the need for an odour AEI was identified as a priority, in response to the need for agri-environmental information and to assess the impacts of agricultural policies on the environment (Masse et al., 2013). In EU countries, in 1989-2008, the average EU pigs and poultry breeding holding posed a threat to the natural environment arising from excessive animal population and stocking density (Sobczyński, 2008). At the same time, a tendency of reducing average stocking density is observed, with high variability between countries in this scope. An example of this variability can be observed in Poland and in Lithuania, which neighbors it. Stocking density in Poland amounts to 38.1 head of cattle and 77.4 pigs per 100 ha of agricultural land, while in Lithuania, stocking density amounts to 24.7 head of cattle and 29.4 pigs per 100 ha of agricultural land. (Statistical yearbook, 2014). Poultry breeding also plays an important role on the market of both countries. The supply of products of animal origin is of fundamental significance on the domestic food market, and this production will mainly be developing in specialized holdings. However the threats resulting from concentration of production may constitute a significant limitation towards production.

The goal of this study was to assess environmental and economic sustainability of agricultural holdings specializing in animal production in Poland and Lithuania.

\section{MATERIAL AND METHODOLOGY}

The research problem was undertaken based on data from the FADN system (Farm ..., 2010). Data is collected according to uniform principles from a representative sample of goods agricultural holdings functioning in the EU. The timeframe of analysis covers the years 2006-2012. Data is currently available for this period (European ..., 2013).

Different agriecological indices are applicable to assessment of environmental sustainability (Belanger et al., 2012, 2015; Harasim, 2013, Lebaco et. al., 2013). The selection of indicators should consider the comparsion of indicators based on various criteria, mainly data availability (Lebaco et.al, 2013). In the case of generally available FADN data, it is only possible to calculate some of them, namely: share of cereals in agricultural land (\%) and stocking density $\left(\mathrm{LU} \cdot \mathrm{ha}^{-1}\right)$. Agriecological assessment was supplemented by material pressure indices characterizing the burden on the environment caused by production resources (Piekut and Machnacki, 2011). These are: indirect consumption, value of mineral fertilizers and plant protection products, value of purchased feed, and energy consumption. These indices indicate the intensity of agricultural management. The index of costs sustained for purchasing mineral fertilizers and plant protection products is of limited value in the assessment of holding sustainability, however it can be of diagnostic value and serve as a criterion in trend assessment (Sobczyński, 2008).

Land profitability and productivity of labor, understood as the total net added value per fully employed person (SE415/SE010), and profitability of labor, or the value of income from a family-owned agricultural holding per fully employed family member (SE430=SE420/SE015), were accounted for in economic sustainability assessment. Aims pertaining to economic areas of sustainability include achievement of an income which provides farmers with a fair life standard (Lawn, 2003; Liu, 2010). Profitability of labor was corrected by the balance of subsidies and taxes (SE600) to provide a complete picture of the economic situation of agricultural holdings.

According to the accepted objective of the study, analyses were conducted in division into two agricultural types of holdings specializing in animal production: dairy cattle (TF45) and granivores, i.e. pigs and poultry (TF51, TF52).

\section{RESULTS}

The holdings subject to study are very diverse in terms of the production factors they are equipped with (Table 1). Lithuanian holdings are characterized by a larger area of agricultural land. This is particularly visible in the case of granivore holdings. Lithuanian holdings are over 3 times larger. In terms of equipment on technical production resources, Polish holdings exhibited better results. There are also distinct differences in the level of employment. In dairy holdings, differences in the level of employment are small, and family members are mainly involved in labor. In Lithuanian granivore holdings, employment is over 4 times greater than in Polish holdings of the same type. These are holdings that are large in area, based mainly on hired labor. The economic size of holdings is a consequence of this variability. Lithuanian dairy holdings are classified as medium-small and Polish as medium-large, and Polish granivore holdings are classified as large and as very large in Lithuania. There are distinct differences in herd size. Lithuanian holdings stand out from this perspective, since they are characterized by high pigs and poultry concentration.

Table 1. Selected characteristics of surveyed agricultural holdings (average 2006-2012)

\begin{tabular}{|l|c|c|c|c|}
\multirow{2}{*}{\multicolumn{2}{|c|}{ Specification }} & \multicolumn{2}{c|}{ Poland } & \multicolumn{2}{c|}{ Lithuania } \\
\cline { 2 - 5 } & dairy cattle & granivores & dairy cattle & granivores \\
\hline Economic size (ESU) & 24.87 & 58.27 & 15.73 & 319.27 \\
\hline Utilised Agricultural Area - UAA(ha) & 19,82 & 21.54 & 29.86 & 78.36 \\
\hline including rented UAA(ha) & 5.80 & 5.50 & 14.12 & 53.33 \\
\hline Total labour input (AWU) & 1.78 & 1.79 & 1.68 & 8.30 \\
\hline Family labour input (FWU) & 1.72 & 1.50 & 1.52 & 1.13 \\
\hline Fixed assets (EUR·ha ${ }^{-1}$ ) & 88995.8 & 10537.4 & 1899.9 & 3552.2 \\
\hline Total livestock unit (LU) & 20.48 & 58.16 & 15.54 & 427.22 \\
\hline including: dairy cattle & 13.50 & 0.18 & 10.07 & 0.40 \\
\hline pigs & 0.49 & 45.60 & 0.28 & 247.36 \\
\hline poultry & 0.01 & 11.78 & 0.03 & 177.06 \\
\hline
\end{tabular}


Crop structure is the basic determinant of the organization of plant production. It is decisive to the production and economic effects, besides the level of fertilization and harvested crops. The crop structure in the holdings under study is typical of the chosen directions of production, however there are differences between Polish and Lithuanian holdings. The share of cereals in the crop structure did not exceed $40 \%$ only in Polish dairy cattle holdings. In Lithuanian dairy cattle holdings, this index was very high and amounted to over $80 \%$ (Table 2). In the case of both countries, in granivore holdings, the share of cereals in the crop structure was also high, although lower in Lithuanian holdings than in Polish holdings (Table 3). In such cases. the ecological equilibrium of agrocoenoses is violated.

Table 2. Agroecological assessment indexes and material pressure indexes in dairy cattle holdings

\begin{tabular}{|c|c|c|c|c|c|c|c|c|}
\hline \multirow{2}{*}{ Specification } & \multicolumn{4}{|c|}{ Poland } & \multicolumn{4}{|c|}{ Lithuania } \\
\hline & 2006 & 2008 & 2010 & 2012 & 2006 & 2008 & 2010 & 2012 \\
\hline Share of cereals in crops (\%) & 38.15 & 39.97 & 35.78 & 36.50 & 83.91 & 84.16 & 81.74 & 82.62 \\
\hline $\begin{array}{l}\text { Number of livestock - stocking density } \\
\left(\mathrm{LU} \cdot \mathrm{ha}^{-1}\right)\end{array}$ & 0.97 & 1.08 & 1.08 & 1.08 & 0.52 & 0.53 & 0.53 & 0.51 \\
\hline $\begin{array}{l}\text { Total intermediate consumption } \\
\left(\text { EUR } \cdot \mathrm{ha}^{-1}\right)\end{array}$ & 618.39 & 888.98 & 751.58 & 933.70 & 1526.44 & 2102.08 & 2536.52 & 3137.42 \\
\hline Mineral fertilizers $\left(\right.$ EUR $\left.\cdot h^{-1}\right)$ & 69.73 & 103.13 & 80.13 & 113.35 & 90.98 & 128.73 & 123.32 & 157.89 \\
\hline Plant protection products $\left(E U R \cdot h^{-1}\right)$ & 18.50 & 25.87 & 20.81 & 22.77 & 37.41 & 53.99 & 55.39 & 61.68 \\
\hline Value of purchased feed $\left(\right.$ EUR $\left.\cdot h^{-1}\right)$ & 212.48 & 350.17 & 278.39 & 375.24 & 294.37 & 212.24 & 243.21 & 249.51 \\
\hline Energy consumption $\left(\right.$ EUR $\left.\cdot \mathrm{ha}^{-1}\right)$ & 90.09 & 122.33 & 114.92 & 141.49 & 51.38 & 67.95 & 69.11 & 81.72 \\
\hline
\end{tabular}

Source: own calculation based on FADN data

According to the principles of good agricultural practice, a share of cereals greater than $66 \%$ in the crop structure should be avoided (Duer et al., 2002). From this perspective, only Polish dairy holdings met these requirements. This situation is rather typical for holdings with this direction of production. Cattle breeding holdings are most frequently located in areas with a large share of permanent grasslands. This is a natural feed base for ruminants. Moreover, these holdings cultivate a large amount of corn for green forage, which is used to feed animals. These factors result in reduction of demand for cereals.

It seems that the high share of cereals in Lithuanian dairy holdings results from the large average area of agricultural land in a holding (29.86 ha). These are holdings that are quaite large in area. Cereals are dominant in the crop structure of such holdings, which is mainly dictated by organizational concerns. Granivore holdings are also deserving of attention. While the crop structure in these holdings did not meet standards of good agricultural practice in 2006 and 2008, the situation improved in 2010 and 2012, and these standards were met. Perhaps this caused a change in the pigs and poultry feeding system. A transition from feeding with self-produced feeds to purchased full-portion mixtures probably took place. Feed purchasing data confirms this (Table 3).

Table 3. Agroecological assessment indexes and material pressure indexes in granivores holdings

\begin{tabular}{|c|c|c|c|c|c|c|c|c|}
\hline \multirow{2}{*}{ Specification } & \multicolumn{4}{|c|}{ Poland } & \multicolumn{4}{|c|}{ Lithuania } \\
\hline & 2006 & 2008 & 2010 & 2012 & 2006 & 2008 & 2010 & 2012 \\
\hline Share of cereals in crops (\%) & 83.91 & 84.16 & 81.74 & 82.62 & 69.90 & 70.59 & 56.74 & 60.07 \\
\hline $\begin{array}{l}\begin{array}{l}\text { Number of livestock - stocking } \\
\text { density } \\
\left(\mathrm{LU} \cdot \mathrm{ha}^{-1}\right)\end{array} \\
\end{array}$ & 2.32 & 2.13 & 3.12 & 2.98 & 4.56 & 5.32 & 5.57 & 6.79 \\
\hline $\begin{array}{l}\text { Total intermediate consumption } \\
\left(\mathrm{EUR} \cdot \mathrm{ha}^{-1}\right)\end{array}$ & 1526.44 & 2102.08 & 2536.52 & 3137.42 & 2346.73 & 4072.85 & 4264.75 & 6411.92 \\
\hline Mineral fertilizers $\left(E U R \cdot h^{-1}\right)$ & 90.98 & 128.73 & 123.32 & 157.89 & 59.18 & 68.98 & 61.52 & 138.16 \\
\hline Plant protection products $\left(\right.$ EUR $\cdot$ ha $\left.^{-1}\right)$ & 37.41 & 53.99 & 55.39 & 61.68 & 29.30 & 38.80 & 46.68 & 64.42 \\
\hline Value of purchased feed $\left(\right.$ EUR $\left.\cdot h^{-1}\right)$ & 1019.88 & 1462.55 & 1781.82 & 2237.66 & 1719.44 & 3110.02 & 3156.86 & 4913.08 \\
\hline Energy consumption $\left(\right.$ EUR $\cdot$ ha $\left.^{-1}\right)$ & 127.82 & 157.25 & 190.44 & 222.46 & 183.23 & 321.99 & 398.32 & 450,14 \\
\hline
\end{tabular}

Organization of livestock production is assessed from the perspective of use of produced manure. The number of animals on a holding and their stocking density are both important. Average stocking density in dairy holdings did not pose a threat to the natural environment because it did not exceed the maximum level of $1.5 \mathrm{LU} \cdot \mathrm{ha}^{-1}$ (Duer et al. 2002). Granivores holdings posed such threats, because the stocking density significantly exceeded the upper stocking limit that has been accepted in good agricultural practice. These results confirm studies conducted in EU countries in previous years (Sobczyński, 2008). Excessive burden on the environment due to pigs and poultry production is the result of a large animal concentration in the herd. Production is conducted in a small area, which results in high animal population per 1 ha of agricultural land.

Total intermediate consumption per 1 ha of farmland is a general indicator of material pressure on the environment. It encompasses direct costs and general holding costs related to the operations of the agricultural holding. Granivores holdings were characterized by the highest intensity of production in both countries, mainly due to high costs of purchasing feed (Table 3). These holdings specialize in fattening of pigs and poultry. In this case, production is based on purchased full-portion mixtures. 
Lithuanian holdings were characterized by a greater intensity of production. More mineral fertilizers and plant protection products were used in dairy holdings, and in granivore holdings, more purchased feed and energy were consumed. Thus, these holdings exerted greater pressure on the environment.

Profitability of land and profitability of labor are among the basic indexes of economic effectiveness, because they determine the degree in which basic production factors are used. The income of a holding changes depending on, above all, production value and sustained costs. Granivore type holdings sustained the highest costs, achieved production of a greater value, and generated more income than dairy cattle holdings (Table 4). In the case of Polish holdings in the years 2006 and 2008, the difference amounted to approx. 863 EUR per person fully employed on the holding $\left(\right.$ EUR $\left.\cdot F W U^{-1}\right)$, and in 2010 and 2012 the difference increased to nearly 7 thousand. This situation was primarily the result of unfavorable economic conditions and climate on the milk market.

There were still greater differences between Lithuanian holdings. In 2006 and 2008, profitability of labor in granivore holdings were more than double that in dairy holdings, the difference being 4012 EUR per person fully employed on a holding. In 2010 and 2012, labor profitability clearly increased in dairy cattle holdings, and the difference in the value of this index between holdings of the types under study decreased (Table 4). This results from changes of the economic conditions of farming; price relations changed for production resources and for the sale of products.

The achievement of this level of income from a family-owned agricultural holding was possible thanks to support from European Union funds. The share of subsidies in income from agricultural activity in dairy farms amounted to $42.8 \%$ on average in Poland and $46.6 \%$ in Lithuania. In granivore holdings, subsidies made up $31 \%$ of income from the holding on average. In the case of Lithuania, in 2006-2010, 61.5\% of income from granivore holdings came from EU subsidies, and in 2012 the share of public support was three times lower and amounted to $19.7 \%$ of the value of income from a family-owned agricultural holding.

There were still greater differences between Lithuanian holdings. In 2006 and 2008, profitability of labor in granivores holdings were more than double that in dairy holdings, the difference being 4012 EUR per person fully employed on a holding. In 2010 and 2012, labor profitability clearly increased in dairy cattle holdings, and the difference in the value of this index between holdings of the types under study decreased (Table 4). This results from changes of the economic conditions of farming; price relations changed for production resources and for the sale of products.

Table 4. Economic assessment characterizing studied farms in the years 2006-2012

\begin{tabular}{|c|c|c|c|c|c|c|c|c|}
\hline \multirow{2}{*}{ Specification } & \multicolumn{4}{|c|}{ Poland } & \multicolumn{4}{|c|}{ Lithuania } \\
\hline & 2006 & 2008 & 2010 & 2012 & 2006 & 2008 & 2010 & 2012 \\
\hline \multicolumn{9}{|c|}{ milk } \\
\hline Production value $\left(\right.$ EUR $\left.\cdot h^{-1}\right)$ & 534 & 556 & 662 & 658 & 340 & 380 & 415 & 375 \\
\hline Net value added $\left(\right.$ EUR $\cdot$ AWU $\left.^{-1}\right)$ & 6314 & 6848 & 7996 & 8093 & 3910 & 6668 & 7231 & 6218 \\
\hline Family farm income $\left(\right.$ EUR $\left.\cdot h^{-1}\right)$ & 534 & 556 & 662 & 658 & 340 & 380 & 415 & 376 \\
\hline Family farm income $\left(\right.$ EUR $\left.\cdot F_{W U}^{-1}\right)$ & 5771 & 6354 & 7774 & 7827 & 5124 & 7367 & 8939 & 8208 \\
\hline $\begin{array}{lll}\begin{array}{l}\text { Family farm } \\
\left(\text { EUR } \cdot \text { FWU }^{-1}\right)\end{array} & \text { income corrected } \\
\end{array}$ & 3411 & 3569 & 4390 & 4451 & 2779 & 3978 & 4799 & 4241 \\
\hline \multicolumn{9}{|c|}{ granivores } \\
\hline Production value $\left(\right.$ EUR $\cdot$ ha $\left.^{-1}\right)$ & 2211 & 2814 & 3547 & 4329 & 3194 & 5728 & 5825 & 9047 \\
\hline Net value added $\left(\right.$ EUR $\cdot$ AWU $\left.^{-1}\right)$ & 7291 & 8044 & 13772 & 14919 & 10188 & 14138 & 8383 & 18168 \\
\hline Family farm income $\left(\mathrm{EUR} \cdot \mathrm{ha}^{-1}\right)$ & 591 & 612 & 925 & 1008 & 541 & 877 & 688 & 1353 \\
\hline Family farm income $\left(\right.$ EUR $\left.\cdot F W U^{-1}\right)$ & 6161 & 7690 & 14191 & 15329 & 11027 & 17514 & 11413 & 11329 \\
\hline $\begin{array}{l}\text { Family farm income corrected } \\
\left(\text { EUR } \cdot \text { FWU }^{-1}\right)\end{array}$ & 4323 & 4469 & 9764 & 12028 & 4912 & 6570 & 3809 & 9095 \\
\hline
\end{tabular}

AWU - Annual Work Unit; FWU - Family Work Unit

Source: own calculation based on FADN data

The achievement of this level of income from a family-owned agricultural holding was possible thanks to support from European Union funds. The share of subsidies in income from agricultural activity in dairy farms amounted to $42.8 \%$ on average in Poland and $46.6 \%$ in Lithuania. In granivores holdings, subsidies made up $31 \%$ of income from the holding on average. In the case of Lithuania, in 2006-2010, 61.5\% of income from granivores holdings came from EU subsidies, and in 2012 the share of public support was three times lower and amounted to $19.7 \%$ of the value of income from a family-owned agricultural holding.

\section{CONCLUSION}

Demanding requirements of consumers as to the quality of produced food as well as protection of natural resources encourage a perspective of an agricultural holding in terms of its relationships with the environment. The presence of goods holdings specializing in specific directions of production indicates progress and development of agriculture. The introduction of new technologies makes it possible for production capabilities to grow. However, this model of development encounters barriers arising from environmental limitations. Social expectations towards agricultural manufacturers are very high and concern the application of environment-friendly technologies, among other things. Combining economic and ecological performance is the primary task that farmers are currently faced with. 
The analysis that was conducted confirms that the direction of production determined by the holding's agricultural type is the factor with the strongest impact on ecological and economic sustainability of agricultural holdings. Animal production causes particular burdens on the environment linked to the concentration and scale of its production.

Crop structure is unfavorable in the majority of the studied holdings due to oversimplification of plant production and elimination of winter crops. Polish holdings specializing in milk production were an exception, where the crop structure met environmental requirements.

In both countries, average stocking density in dairy holdings did not pose a threat to the natural environment. In the case of granivores holdings, such threats were present because standards specified in the code of good agricultural practice were violated significantly. From the perspective of economic effects, holdings from this group achieved a better result than dairy cattle holdings. In Poland during the years 2006-2012, the average income of a family-owned agricultural holding per full-time worker in the family was $56 \%$ greater than in dairy cattle holdings. In the case of Lithuanian holdings, the difference was still greater and amounted to $73 \%$ to the benefit of granivores holdings.

Holdings of this type also exerted the most pressure on the environment. The production intensity index was greater than in dairy holdings. While their use of technologies allowed for better economic effects, these technologies also posed a burden to the environment. This shows that combining economic and ecological objectives is not an easy task. Nevertheless, it remains a task and challenge for swine and poultry producers in the near future, particularly since subsidization of agricultural holdings with EU funds is contingent upon the achievement of environmental objectives in agricultural activity.

\section{REFERENCES http://dx.doi.org/10.1016/j.ecolind.2014.12.014}

1. Belanger, V., Vanasse, A., Parent, D., Allard, G., Pellerin, D. 2012. Development of agri-environmental indicators to assess dairy farm sustainability in Quebec Eastern Canada. Ecological Indicators, Vol. 23, pp. 421-430. http://dx.doi.org/10.1016/j.ecolind.2012.04.027

2. Belanger, V., Vanasse, A., Parent, D., Allard, G., Pellerin, D. 2015. Delta: an integrated indicator- based self-assessment tool for the evaluation of dairy farms sustainability in Quebec Canada. Agroecology and Sustainable Food Systems, Vol. 39, Iss. 9, pp. 1022-1046. http://dx.doi.org/10.1080/21683565.2015.1069775

3. Castoldi, N., Bechini, L. 2010. Integrated sustainability assessment of cropping systems with agro-ecological and economic indicators in northern Italy. European Journal of Agronomy, Vol. 32, Iss. 1, pp. 59-72. http://dx.doi.org/10.1016/j.eja.2009.02.003

4. Desjeux, Y., Dupraz, P., Kulhman, T., Paracchini, M.L., Michels, R., Maigne, E., Reinhard, S. 2015. Evaluating the impact of rural development measures on nature value indicators at different spatial levels: applications to France and The Netherlands. Ecological Indicators, Vol. 59, Spec. Iss., pp. 41-61. http://dx.doi.org/10.1016/j.ecolind.2014.12.014

5. Duer, I., Fotyma, M., Madej, A. 2002. Kodeks dobrej praktyki rolniczej, NRiRW-MŚ-FAPA, Warszawa.

6. Escribano, A. J., Gaspar, J. P., Mesias, F. J. D., Moreno, A. F. P., Escribano, M. 2014. A sustainability assessment of organic and conventional beef cattle farms in agroforestry system: the case of the "dehesa" rangelands. ITEA - Informacion Tecnica Economica Agraria, Vol. 110 (4), pp. 343-367.

7. European Commission Agricultural and Rural Development. 2013. FADN, Standard reports. Available at: http://ec.europa.eu/agriculture/rica/database/database_en.cfmm (accessed on 10/08/2015)

8. Farm Accountancy Data Network. 2010. An A to $\mathrm{Z}$ of Methodology. European Commission. Available at: http://ec.europa.eu/agriculture/rica/pdf/site_en.pdf

9. Harasim, A. 2013. Metoda oceny zrównoważonego rozwoju rolnictwa na poziomie gospodarstwa rolnego, Studia i Raporty 32(6), IUNG-PIB, Puławy.

10. Lawn, P. A. 2003. A theoretical foundation to support the Index of Sustainable Economic Welfare (ISEW), Genuine Progress Indicator (GPI) and other related indexes. Ecological Economics, Vol. 44, Iss. 1, pp. 105-118.

11. Lebaco, T., Baret, P. V., Stihmant D. 2013. Sustainability indicators for livestock farming. A review. Agronomy for Sustainable Development, Vol. 33, Iss. 2, pp. 311-327. http://dx.doi.org/10.1007/s13593-012-0121-x

12. Liu, Y. 2010. Establishing modern concept of wealth. Promoting Chinese social sustainable development. Journal of Sustainable Development, Vol. 3, Iss. 4, pp. 248-251.

13. Masse, D.I., Narjoux, A., Cournoyer, M., Page, T. 2013. Development of a scientifically sound agri-environmental indicator tool to address the odour issue. Air Quality Atmosphere and Heath, Vol. 6, Iss. 1, pp. 225-237.

14. Piekut, K., Machnacki, M. 2011. Ocena ekologiczno-ekonomiczna gospodarstw rolnych na podstawie danych FADN. WodaŚrodowisko-Obszary Wiejskie, Vol. 11, Iss. 1, pp. 203-219. (In Polish)

15. Sobczyński, T. 2008. Zmiany poziomu zrównoważenia gospodarstw rolnych UE w latach 1989-2005. Roczniki Nauk Rolniczych, Seria G 94(2), pp. 106114. (In Polish)

16. Statistical Yearbook, Central Statistical Office, Warszawa 2014.

17. Woś, A. 1998. Rozwój zrównoważony. Encyklopedia Agrobiznesu, Fundacja Innowacji, Warszawa. (In Polish) 